\title{
READERS
}

Journal of Management Info (JMI)

ISSN:2313-3376

www.readersinsight.net/jmi

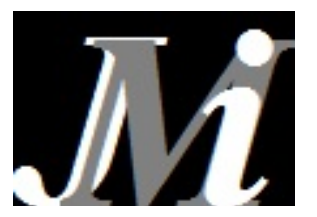

\section{Bank specific and macroeconomic determinants of bank profitability}

\author{
Muhammad Ehsan Javid ${ }^{1}$ \\ ${ }^{1}$ Management Sciences, Lahore Leads University, Lahore Pakistan \\ * Corresponding author: muhammadehsanjavaid@yahoo.com
}

\begin{abstract}
This study investigated the profitability of the banking sector in Pakistan. It evaluated the effects of both internal (bank-specific) and external (macroeconomic) factors on bank's profitability from 2006 to 2013 period. The data of 34 commercial banks operating in Pakistan was collected. The data was balanced panel data and analyzed by random effect panel data regression analysis. Results confirmed that bank size and non-interest income had positive significant relationship on banking profitability. Deposit had negative significant relationship with banking profitability because of maintaining high liquidity which increased cost of holding asset that ultimately decrease profitability. As major participant banks of Pakistan banking sector were small size banks, so most important factor out of significant factors was income from non-interest facilities provided by these commercial banks. By increasing such facilities increased the bank's customer base which ultimately increased bank's profitability. Macro-economic factors showed no significant effect on bank's profitability.
\end{abstract}

ARTICLE INFORMATION

\section{Received: 25 April 2016 \\ Revised: 25 May 2016 \\ Accepted: 25 June 2016}

DOI:

http://dx.doi.org//10.31580/jmi.v10i1.46

\section{Introduction}

Financial sector provided roadmap for global economic growth and development. In Pakistan commercial banks, microfinance banks, leasing companies, investment banks, house finance companies, development finance institutions, Islamic banks, insurance companies, stock exchanges and mutual funds were the main parties that contributed and constituted in financial sector formation. Commercial banks (including Islamic banks), development finance institutions and microfinance banks all were regulated under the umbrella of State Bank. Due to globalization and financial integration, national and international level focused on financial system stability and sustainability. Capital flow domestically and international was highly dependent on the soundness of domestic financial system of a country and its capability to absorb volatilities and protect investors. Commercial banks were the main players of global financial system and specially in Pakistan. Globalization affected Pakistan's financial system very significantly that was the reason in 1997 banking system and supervision was brought in line to international best practices. New private banks along with privatization of public sector banks, change in ownership structure because of increase merger and acquisition were visible outcomes of structural changes. In Pakistan for sound and flexible financial system commercial banks needed to be more profit oriented for increased competition domestically and internationally.

Athanasoglou et al. (2008) confirmed that countries with strong and profitable banking industry successfully faced financial crisis and recovered quickly from crisis and reduced its negative impact on economy. US financial crisis of $2008-2009$ and European financial crisis indicated the impact of different macro economical activities on banking sector decisions and result associated with those decisions. Problems faced by banking system due to decreased GDP (Gross Domestic Product) and increased inflation further intensified the problems. Profitability in any business was not limited to internal business environment but external environment also affected business profitability in different ways. Financial crisis in US had spillover effects in all countries due to direct and indirect association with world biggest economy.

Question that needed to be addressed now that what were those changes observed in Pakistan banking sector after US financial crisis and what were those factors which were responsible for bank's profitability. Previously all the studies on profitability determinants of Pakistani banking sector included only firm specific sectors while in this study bank specific factors along with some macroeconomic factors were also used for research. Reason behind including these macroeconomic factors was financial liberalization because of which many macroeconomic factors directly affecting bank's profitability. All those bank specific factors which were used in this study were historically used by different researchers which were discussed in next section of literature review. Along with that major macroeconomic factor like GDP, inflation and real interest rate were also considered because of direct relation of these factors on banking operations.

\section{Literature review}

In this section an overview of previous studies were presented which focused on the identification of factors responsible for banking profitability. These studies were either country specific or comparative analysis among different counties. Normally in order to check profitability of banks return on assets (ROA), return on equity (ROE) and net interest margin (NIM) were used, which means that these were dependent variables, however independent side of variables consists of internal factors of banks only. Banking profitability determinants analysis started by Short (1979). However similar but advanced level of work was done by Bourke (1989), in which he used capital ratio, credit risk, productivity growth and size of the bank as independent internal factors responsible for bank 
profitability. He studied banking sectors of Australia, North America and Europe. Result confirmed significant positive relation among capital adequacy and bank profitability. Angbazo (1997) focused on the bank specific factors like management efficiency, leverage, cost of non-interest bearing reserves and default risk in US banking sectors and concluded that banks with more risky loans and higher interest rate risk exposure normally select those loans and deposit rates in order to achieve high profitability showed positive relationship. Default risk affected the profitability in a negative way of money centered banks while regional banks were more negatively affected by interest rate risk then default risk.

Demirgüç-Kunt and Huizinga (1999) In their comprehensive study checked which internal factors responsible for the banking profitability across 80 different countries. It incorporated different developed and developing countries from 1986 to 1999. Result depicted that well capitalized banks had low default risk which increased bank profitability. Bank profitability had direct positively related with operating efficiency and capital ratio. Barajas, Steiner, and Salazar (1999) conducted deep investigation on Colombian banking sector profitability and concluded that due to increase financial integration and liberalization, demand for loan increased. Due to intervention of new international parties in market quality of loan improved, but it didn't reduce the interest spread which was main source for bank profitability.

Similar study on bank profitability were conducted by Guru, Staunton, and Balashanmugam (2002) on seventeen commercial banks of Malaysia from 1986 to 1995. Results showed efficient expense management by banks lead to high profitability in Malaysia by highlighting that Malaysian banks were generating maximum amount of profits from efficient expense management in the period of study. Claessens, Demirgüç-Kunt, and Huizinga (2001) performed cross country analysis among banks of 80 countries from 1988 to 1995. They examined impact of foreign banks on domestic banks profitability. Result showed that foreign banks decreased profitability of domestic banks in developing countries while in developed countries profitability of domestic banks were higher than foreign banks. This study identified a gap that not only bank specific factor but different external factors like developing countries policy to attract foreign direct and portfolio investment by providing protection on tax, interest rates and exchange rate $\mathrm{s}$ etc. affected profitability potential of banks.

Naceur (2003) took step further in this domain of research by incorporating bank specific and external factors to check determinants of profitability in Tunisian banking sector from 1980 to 2000. Results showed that bank specific factors were more important factors for profitability. Loans had positive relationship. No macroeconomic variables had impact on profitability. Mamatzakis and Remoundos (2003) found significant effect of bank expenses, amount of loans in total assets and equity investment in asset on determining bank profitability. A comparative analysis between Islamic and conventional banks in GCC countries was performed by Alkassim (2005) time period of study was from 1997 to 2004. He identified profitability determinants by considering internal and external factors. Results confirmed that asset quality of conventional banks was better than Islamic banks. However Islamic banks interest free lending increased their profitability but put negative impact on conventional banks profitability. Total expenses decreased conventional banks profitability potential.

Al-Hashimi (2007) performed an extension on study by Naceur (2003) in 10 SSA countries. Result showed that credit risk along with operating incompetence were the main factors that decreased profitability of banks. Macroeconomic factors had limited effects on profitability due to indirect relationship. GÜNGÖR (2007) after analyzing previous studies from literature, was compelled to give a more comprehensive definition of bank profitability that internal and external factors were responsible for it. Internal factors included the bank specific factors while the external factors included economic and legal environment of the country which were affecting the profitability. Dietrich and Wanzenried (2009) performed study on
Swiss banks. Results confirmed that bank size and GDP had positive relationship with profitability while interest income had negative impact on profitability because of exploitation of funds for lends for lending. Banks needed to go for more non-interest investment projects in order to increase profitability.

Huge literature is available on determinants of bank profitability globally but a very little work has been carried out on Pakistan banking sector. The studies were conducted on Pakistan banking Ataullah, Cockerill, and Le (2004), Burki and Niazi (2010) and Javaid (2011). Ataullah et al. (2004) conducted comparative study among India and Pakistan banking sector and concluded that both countries banking sector need to improve their banking efficiency. Time period of study was from 1988 to 1998 . Data employment analysis was performed to measure technical efficiency. It was also found that banks were efficient in generating asset then loan due to nonperforming loans. Burki and Niazi (2010) checked impact of financial reforms on efficiency of banking sector of Pakistan. They included domestic, state owned, private and foreign banks. Study incorporated data from 1991 to 2000. Major restructuring in 1997 also cover in this study. Result showed that foreign and private banks hold more efficiency then state owned banks. Results also showed that nonperforming loans and efficiency had negative relationship. Javaid (2011) performed study to determine bank specific factor responsible directly for profitability from 2004 to 2008. Top 10 banks were considered for analysis. Results indicated that higher total sales didn't lead to profitability due to diseconomies of scale. Deposits had significant impact on profitability.

Above discussion clearly showed a wide gap that banking profitability determinant studies in Pakistan were focused only on internal factors. This paper filled this gap by focusing on definition of GÜNGÖR (2007), so incorporated both bank specific factor and macro-economic factors that were used by Naceur (2003) like GDP in addition to that inflation and real interest rates because both affected firm profitability.

\section{Research methodology}

\section{Data}

Data in this study was collected from secondary source i.e. State Bank of Pakistan, Financial Statement Analysis of Financial Sector. However macroeconomic data was collected from World Bank database. Total 34 banks data from 2006 to 2013 were used for analysis in this study. All commercial banks were included. A selection criterion for bank was to be operational throughout study time period.

\section{Variables}

Following were the variables used in this research.

\section{Bank specific independent variables}

As internal factors were determined by bank's management decisions and policy objectives, such as asset size, capital adequacy, liquidity, interest income and non-interest income.

Bank Size: it was measured by natural logarithm of Bank's Total Asset. It was expected to have positive relationship between bank size and bank profitability (Smirlock, 1985).

Liquidity: After US subprime crisis liquidity was most serious concern for banking sector. Current ratio gives us good picture for working capital management prospective but now banks were more dynamic then it was. Now banking sector had diverse asset structure so to get actual position of liquidity, it must be divided by total assets. It was ratio of liquid assets to total assets. Higher value indicated bank good liquidity position which lead to profitability (Bourke, 1989) but along with high cost of holding liquid assets. US crisis confirmed weak liquidity leads to bank failure (Molyneux \& Thornton, 1992).

Deposit: It was calculated as the ratio of total deposit to total assets of the bank. It was main source for collection of funds for banks. A bank with higher deposit amounts was capable of lending more money as loan which increased the profit potential of the bank. It indicated a 
positive relationship with profitability. There was cost associated with these deposits which set the minimum level from which rate of interest must be large in order to earn profit (Demirgüç \& Kunt, 1999).

Non-Interest Income: It was the ratio of non-interest income to total asset bank hold. It explained us about how much bank dependent on these non-interest activities like transaction fees, non-sufficient funds fees, annual fees, monthly account service charges, inactivity fees and many more. It also showed bank diversified operations from its core activities (Demirgüç \& Kunt, 1999).

\section{Macroeconomic independent variables}

Banks profitability was expected to be sensitive to macroeconomic variables. In the literature in terms of external determinants, generally three macroeconomic variables were used: Annual real gross domestic product growth rate (GRR), annual inflation rate (INF) and Real Interest Rate (RIR).

Annual GDP Growth Rate explained us about country's economic progress over the period of year. Higher value was demanded and it represented country's good economic performance. Literature confirmed that GDP growth had association with banking sector profitability. It was expected to have positive association between because when country was economically progressing then it turns its banking sector on similar path (Bikker and $\mathrm{Hu}, 2002$ ).

Annual Inflation Rate measured through Consumer Price Index (CPI) for all goods and services. It disturbed actual cost and returns. Higher value showed larger disturbance between actual cost and return balance. If inflation was anticipated then it had positive association with commercial bank profitability. It increased revenues of bank as inflation was already adjusted. If inflation was unadjusted, it increased cost and reduce revenue which showed negative association with commercial bank profitability (Hassan \& Bashir, 2003; Kosmidou, 2008; Pasiouras \& Kosmidou, 2007)

Real Interest Rate was difference between nominal interest rate minus inflation rate. Higher real interest rate value pointed high loan rates which increased bank overall revenue. Islamic banks profitability also increased through investments and other trading activities where real interest rate was used as hurdle rate. It indicated a positive relationship between real interest rate and bank profitability. A negative relationship when demand for loan is low(Bourke, 1989).

\section{Dependent variable}

Proxy for bank profitability used in this study was return on asset. In the literature, banks profitability, typically measured by return on asset (ROA). ROA was defined as net profit divided by total assets and was expressed in percent. It was a general measure for bank profitability reflects bank ability to achieve return on its sources of fund to generate profits.

\section{Research model}

ROA $_{t}=\beta_{0}+\beta_{1}$ BankSize $_{\mathrm{t}}+\beta_{2}$ Deposit $_{\mathrm{t}}+\beta_{3}$ Liquidity $_{\mathrm{t}}+\beta_{4}$ Noninterestin come $_{\mathrm{t}}+\beta_{5}$ AnnualInflation ${ }_{\mathrm{t}}+\beta_{6}$ Growthrate $_{\mathrm{t}}+\beta_{7}$ Realinterestrate $+\mathrm{u}_{\mathrm{t}}$

Table 1: Varables and Measurements

\begin{tabular}{|c|c|c|}
\hline Variable Name & Symbol & Measurement \\
\hline Profit & ROA & Net Profit Divided By Total Assets \\
\hline Bank Size & BS & $\begin{array}{l}\text { Natural Logarithm Of Bank's Total } \\
\text { Asset }\end{array}$ \\
\hline Deposit & DEP & Deposit to Total Assets \\
\hline Liquidity & LQD & $\begin{array}{l}\text { Ratio of Liquid Assets to Total } \\
\text { Assets }\end{array}$ \\
\hline $\begin{array}{l}\text { Non- Interest } \\
\text { Income }\end{array}$ & $\mathrm{NII}$ & Non-Interest Income/Total Asset \\
\hline $\begin{array}{l}\text { Annual inflation } \\
\text { rate }\end{array}$ & INF & Consumer Price Index (CPI) \\
\hline $\begin{array}{l}\text { GDP Growth } \\
\text { rate }\end{array}$ & GRR & World Bank Database \\
\hline $\begin{array}{l}\text { Real Interest } \\
\text { Rate } \\
\text { Error Term }\left(U_{t}\right)\end{array}$ & RIR & $\begin{array}{l}\text { Nominal Interest Rate Minus } \\
\text { Inflation Rate }\end{array}$ \\
\hline
\end{tabular}

\section{Data Analysis}

\section{Descriptive statistics}

Total 272 panel observation were included in the study which indicated that mean profit for any bank in that time frame was $0.18536 \%$ with exception that some banks face loss up to $22 \%$ and profit up to $5.30 \%$. Liquidity position of banks was quite good to prudent regulations due to Pakistan's banking sector perform well during US financial crisis which was learned by Pakistan's banking sector from previous financial crises in different regions. Non-interest income for bank during this study period was $16.75 \%$ which increased up to $63.4 \%$ while deposit was on average $65.07 \%$ which increased up to $90.85 \%$. However only Al-Baraka bank in 2006 had zero noninterest income and zero deposits. Mean growth rate was 3.75\% while inflation is $11.57 \%$ and real interest rate is $0.27955 \%$. In the study time frame from year 2008 to 2011 the growth rate decreased up to $1.606 \%$, inflation increased up to $20.28 \%$ and real interest rate decreased up to $-6.774 \%$ due to major domestic terrorism and international financial crisis but in the latter stages the macroeconomic condition show improvement.

\begin{tabular}{r|rrrrr} 
Variable & Obs & Mean & Std. Dev. & Min & Max \\
\hline Profit & 272 & .0018536 & .0260973 & -.221694 & .0530341 \\
Liquidity & 272 & .1480792 & .1608972 & .0170673 & .9946816 \\
BankSize & 272 & 18.15686 & 1.575686 & 14.7109 & 21.26284 \\
NonIntIncome & 272 & .1675447 & .1094817 & 0 & .6340509 \\
Deposit. & 272 & .6507161 & .2330833 & 0 & .9085466 \\
\hline Growth & 272 & 3.752689 & 1.70165 & 1.606681 & 6.177542 \\
Inflation & 272 & 11.57827 & 4.091738 & 7.598684 & 20.28612 \\
Realinterest & 272 & .2795529 & 4.872329 & -6.774088 & 7.463812
\end{tabular}

\section{Correlation analysis}

The correlation analysis showed that profitability of the bank decreased with increased liquidity because bank took aggressive attitude toward liquidity problem and some bank hold almost $99 \%$ of liquid assets to total asset which decrease their profitability potential. Inflation also indicated a negative relationship because increased inflation leads to refinancing and reinvestment risks to bank. Bank size showed negative relationship with liquidity because large bank easily loan to meet their liquidity requirements. Large banks hold flexible working capital policy. Non-interest income of large banks decreased because large bank diversified their operations to other non-banking ventures. Deposit had negative relation with liquidity because when bank hold such large amount of liquid asset to meet liquidity requirement then it had less amount to lend out to earn profit as a result it pays less amount to depositors. As large banks are involved in other non-banking activities because their growth potential decreased with increased size of their business.

Profit Liguidøy BankSize Noninten Deposit Grouth Inflatnn Realinot

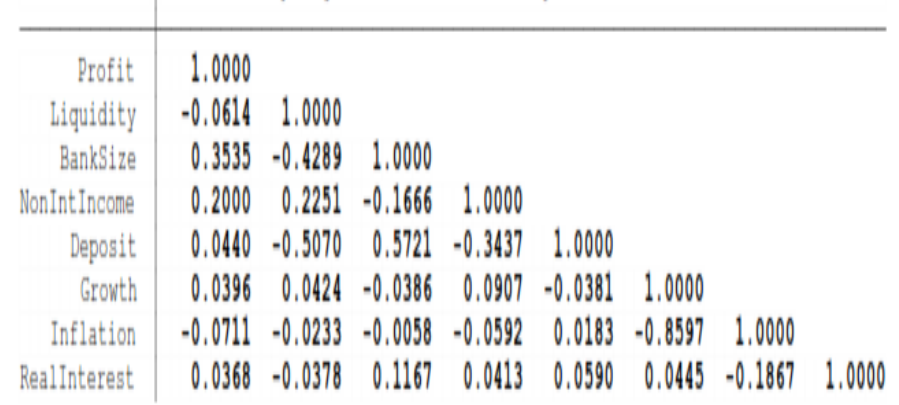




\section{Hausman test and breusch and pagan test}

Hausman test was performed to check whether fixed effect panel data regression analysis was appropriate for the study or random effect panel data regression. Insignificant Chi-Square value showed that random effect panel data regression analysis was appropriate.

i) Null Hypothesis: Random Effect Model

ii) Alternative Hypothesis: Fixed Effect Model

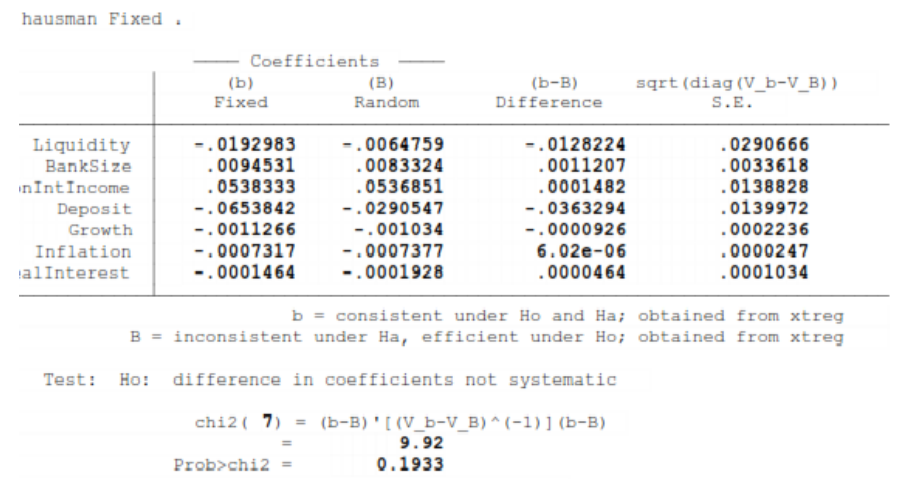

Breusch \& Pagan Test was performed as an alternative to confirmed that either random effect panel data regression analysis was appropriate or pooled regression analysis was more appropriate. Significant Chi-Square showed that random effect panel data regression analysis was appropriate.

i) Null Hypothesis: Pooled Regression

ii) Alternative Hypothesis: Random Effect Model

Breusch and Pagan Lagrangian multiplier test for random effects

Profit $[$ CName, $t]=X b+u[$ CName $]+e[$ CName, $t]$

Estimated results:

\begin{tabular}{r|cc} 
& Var & sd $=$ sqrt (Var) \\
\hline Profit & .0006811 & .0260973 \\
e & .0004471 & .0211442 \\
$u$ & .0000991 & .0099562
\end{tabular}

Test: $\operatorname{Var}(\mathrm{u})=0$

Prob $\frac{\text { chibar2 (01) }}{>\text { chibar2 }=} \begin{array}{r}21.57 \\ 0.0000\end{array}$

\section{Random effect panel data regression analysis}

Random effect regression analysis result showed that model explained $8.32 \%$ changes within the cross sectional entity while $41.47 \%$ changes across the cross sectional entities however it efficiently explain $20.47 \%$ overall changes while rest was unexplained due to untapped factors. Results also indicated that $18.14 \%$ of the change is due to difference across the cross sectional entities. Significant F-statistics value confirmed the appropriateness of model. Balanced panel observations were used for analysis. Result showed that bank size (BS) had positive significant relationship with profitability of bank. It means that larger the bank size, more resources were available to diversify its operations to both banking and non-banking operations to reduce risk which ultimately lead to increase profitability for bank. Results supported the results from correlation analysis. Descriptive statistics highlighted that large bank score more profits and vice versa.

Non-interest income also showed positive significant relation with bank profit. It means that bank was efficiently providing different facilities to its customer which led to increase bank profit. Correlation analysis already confirmed the similar result. However one point was prominent that there was negative association between bank size and non-interest income in correlation analysis. When bank size increased it leads toward other non-banking operations to diversify it risk as it efficiently exploited all facilities to generate non-interest income for bank. One more prominent thing in the result was that a coefficient value for non-interest income was 0.05368 while bank size coefficient value was 0.00833 which make non-interest income more important factor for profitability. It is because our data set included majorly new small banks with few large size banks. This result also confirmed the appropriateness of model that it efficiently explaining changes between the cross section entities.

Deposit showed negative significant relation with bank profit. It means that if bank want to increase the profitability then it had to reduce deposit bank hold. The reason was already discussed in correlation analysis i.e. due to liquidity risk bank perform practiced aggressive working capital policy as a result of which a large amount of deposit held by bank while small amount of cash was lent out. It decreases the liquidity risk of bank but it also increased the cost of holding deposit which reduces the profitability of bank. Descriptive statistics confirmed that Oman International Bank hold more than $90 \%$ of total assets as liquid asset. Carrying cost was considered less dangerous by Pakistani banks as compared to financial shortage cost learned from previous financial crises in different regions of world. In this way Pakistan banking sector keep high liquidity position which protected them from direct and indirect effects of US financial crisis. It highlighted that Pakistan banking sector was not affected by US financial crisis because of proactive approach and more indirect nature of association in markets.

Although good liquidity position increased the profitability of the bank but Pakistani bank hold quite high proportion of liquid asset which increases their cost of holding asset due to which the profitability of bank decreases. However insignificant negative association is confirmed from analysis. All the macroeconomic variables had insignificant negative relationship with bank profitability. Reason for insignificance relationship was strong prudential regulations that keep banking sector of Pakistan protected from US financial crisis however these regulations directed bank to keep handsome amount for liquidity protection which ultimately reduced the profitability of banks.

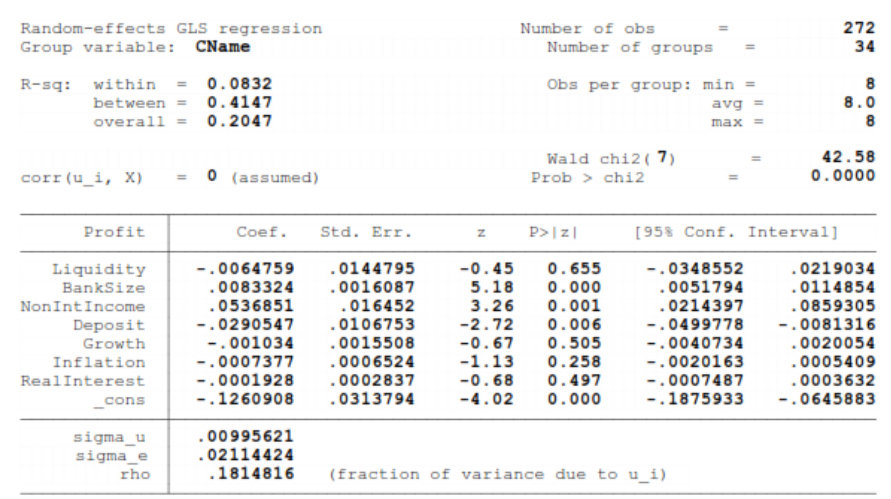

\section{Conclusion}

Banks are positioned as the backbone of financial system in any country. This study had specially focused to identify bank specific and macroeconomic factors of bank profitability in pre and post crisis era. Main bank specific factors according to literature were liquidity, bank size, non-interest income and deposit while macroeconomic factors were GDP growth rate, inflation and real interest rate. The results showed that only bank specific factors were affecting bank profitability while macroeconomic factors showed insignificant effect on bank profitability. Out of bank specific factors, increase in bank size and non-interest income increased the profitability of bank in Pakistan while high deposit decreased the profitability because of maintaining high liquid asset which increased the cost of holding asset that ultimately decreases profitability. As major participant banks of Pakistan banking sector were small size bank so most important factor out of significant factors were income from non- 
interest facilities provided by commercial banks. More the facilities bank provided increased the customer base which ultimately increased bank's profitability. This study confirmed that Pakistan banking sector considered carrying cost less dangerous as compared to financial shortage cost. High liquidity positions maintained by Pakistan banking sector which protected them from direct and indirect effects of US financial crisis. It confirmed that Pakistan banking sector was not affected by US financial crisis due to proactive approach and more indirect nature of association between markets.

\section{References}

Al-Hashimi, A. (2007). Determinants of bank spreads in Sub-Saharan Africa. Draft kindly provided by the author.

Alkassim, F. A. (2005). The profitability of Islamic and conventional banking in the GCC countries: A comparative study. Journal of Review of Islamic Economics, 13(1), 5-30.

Angbazo, L. (1997). Commercial bank net interest margins, default risk, interest-rate risk, and off-balance sheet banking. Journal of Banking \& Finance, 21(1), 55-87.

Ataullah, A., Cockerill, T., \& Le, H. (2004). Financial liberalization and bank efficiency: a comparative analysis of India and Pakistan. Applied Economics, 36(17), 1915-1924.

Barajas, A., Steiner, R., \& Salazar, N. (1999). Interest spreads in banking in Colombia, 1974-96. IMF Staff Papers, 196-224.

Bourke, P. (1989). Concentration and other determinants of bank profitability in Europe, North America and Australia. Journal of Banking \& Finance, 13(1), 65-79.

Burki, A. A., \& Niazi, G. (2010). Impact of financial reforms on efficiency of state-owned, private and foreign banks in Pakistan. Applied Economics, $42(24), 3147-3160$.

Claessens, S., Demirgüç-Kunt, A., \& Huizinga, H. (2001). How does foreign entry affect domestic banking markets? Journal of Banking \& Finance, 25(5), 891-911.

Demirgüç-Kunt, A., \& Huizinga, H. (1999). Determinants of commercial bank interest margins and profitability: some international evidence. The World Bank Economic Review, 13(2), 379-408.
Dietrich, A., \& Wanzenried, G. (2009). What determines the profitability of commercial banks? New evidence from Switzerland. Paper presented at the 12th Conference of the Swiss Society for Financial Market Researches, Geneva. Discussion Paper.

GÜNGÖR, B. (2007). Türkiye'de faaliyet gösteren yerel ve yabancı bankaların kârlllık seviyelerini Etkileyen faktörler: Panel veri analizi. Iktisat Isletme ve Finans, 22(258), 40-63.

Guru, B. K., Staunton, J., \& Balashanmugam, B. (2002). Determinants of commercial bank profitability in Malaysia. Journal of Money, Credit, and Banking, 17, 69-82.

Hassan, M. K., \& Bashir, A.-H. M. (2003). Determinants of Islamic banking profitability. Paper presented at the 10th ERF Annual Conference, Morocco.

Javaid, S. (2011). Determinants of bank profitability in Pakistan: Internal factor analysis. Department of Management Sciences. Correspondence concerning this article should be addressed to Khalid Zaman, Department of Management Sciences, COMSATS Institute of Information Technology.

Kosmidou, K. (2008). The determinants of banks' profits in Greece during the period of EU financial integration. Managerial Finance, 34(3), 146-159.

Mamatzakis, E., \& Remoundos, P. (2003). Determinants of Greek commercial banks profitability, 1989-2000. Spoudai, 53(1), 84-94.

Molyneux, P., \& Thornton, J. (1992). Determinants of European bank profitability: A note. Journal of Banking \& Finance, 16(6), 1173-1178.

Naceur, S. B. (2003). The determinants of the Tunisian banking industry profitability: panel evidence. Universite Libre de Tunis working papers.

Pasiouras, F., \& Kosmidou, K. (2007). Factors influencing the profitability of domestic and foreign commercial banks in the European Union. Research in International Business and Finance, 21(2), 222-237.

Short, B. K. (1979). The relation between commercial bank profit rates and banking concentration in Canada, Western Europe, and Japan. Journal of Banking \& Finance, 3(3), 209-219.

Smirlock, M. (1985). Evidence on the (non) relationship between concentration and profitability in banking. Journal of Money, Credit and Banking, 69-83.

\section{Appendix A}

\begin{tabular}{rlrl} 
Name of banks used in this study & & \\
\hline Sr. & Bank Name & Sr. & Bank Name \\
\hline 1 & First Women Bank Limited & 18 & Meezan Bank Limited \\
2 & National Bank Of Pakistan & 19 & The Punjab Provincial Cooperative Bank \\
3 & The Bank Of Khyber & 20 & Nib Bank \\
4 & The Bank Of Punjab & 21 & Samba Bank Limited \\
5 & Albaraka (Pakistan) Limited & 22 & Silkbank Limited \\
6 & Allied Bank Limited & 23 & Soneri Bank Limited \\
7 & Askari Bank Limited & 24 & Standard Chartered Bank (Pakistan) Limited \\
8 & Bank Al-Habib Limited & 25 & Summit Bank \\
9 & Bank Alfalah Limited & 26 & United Bank Limited \\
10 & Bank Islami Pakistan Limited & 27 & Industrial Dev. Bank Of Pakistan \\
11 & Dubai Islamic Bank Pakistan Limited & 28 & Sme Bank Ltd. \\
12 & Faysal Bank Limited & 29 & Zarai Taraqiati Bank Ltd. (Ztbl) \\
13 & Habib Bank Limited & 30 & Citi Bank N. A. \\
14 & Habib Metropolitan Bank Limited & 31 & Deutsche Bank \\
15 & Js Bank & 32 & Hsbc Bank Middle East Limited \\
16 & Kasb Bank Limited & 33 & Oman International Bank Saog. \\
17 & Mcb Bank Limited & 34 & The Bank Of Tokyo-Mitsubishi, Limited \\
\hline
\end{tabular}

